\title{
The impact of the coronavirus pandemic on the dividend target payout ratio. The evidence from Hydrotor SA
}

\section{Mieczysław Kowerski}

Academy of Zamość

E-mail:

mieczyslaw.kowerski@upz.edu.pl ORCID: 0000-0002-2147-2037

\section{Marcin Sowa}

Academy of Zamość

E-mail:marcin.sowa@upz.edu.pl ORCID: 0000-0002-5235-4156
Publication financed by: Małopolska School of Economics in Tarnów

Correspondence to: Mieczysław Kowerski Akademia Zamojska Instytut Społeczno-Ekonomiczny ul. Pereca 2

\begin{abstract}
Lintner's (1956) partial adjustment model identifies the company's long-term dividend policy by setting a dividend target payout ratio and the speed of adjustment. And although the model has undergone various modifications and methods of estimation have changed over more than 60 years, it is still a good tool for analyzing dividend decisions made by companies. The aim of the article is to show the usefulness of the Lintner model for analyzing changes in the company's dividend policy during the pandemic turmoil. For the illustration, Hydrotor SA was chosen, which, the longest time at the Warsaw Stock Exchange, continuously pays dividends. The calculations showed that the situation in 2020 resulted in a revision of the company's long-term dividend strategy, which resulted in a lowering of the dividend target payout ratio and a greater attention to the current situation (current net profits) — an increase in the speed of adjustment.
\end{abstract}

Keywords: Lintner model, dividend target payout ratio, coranavirus pandemic, Hydrotor SA

\section{Introduction}

The decision to pay a dividend - whether to pay it and, if so, how much to pay?, is one of the most important financial decisions made by each company. This decision is usually the result of the company's long-term dividend policy. For more than 60 years, the Lintner (1956) partial adjustment model has been used to assess the dividend policy of companies. Model assumes that the dividend paid for year $t$ depends on the income earned in that year and on the dividend paid for the previous year. Estimation of Lintner model allows to identify the company's (or groups of companies e.g. of specified sector) long-term dividend policy by setting a dividend target payout ratio and the speed of adjustment at which dividend payouts adjust.

Model proposed by Lintner has found great recognition among theorists and financial practitioners, and for more than 60 years the results of its estimates have been published for dif- 
ferent periods, different companies and financial markets of different countries. The extent of this model can be evidenced, for example, by Fernau and Hirsch's (2019) recently published results of a regressive meta-analysis, for which the authors analyzed 979 models in 99 articles. Over time, Lintner's model has been subject to modifications consisting in its expansion with further variables (Fama and Babiak, 1968), (Fama and French, 2002), the introduction instead of net profit of other indicators describing income (cash flow, operating profit) and, above all the growing number of companies analyzed and the transition from a pool regression approach to a panel regression approach. With the development of econometrics, estimation methods also changed. The Lintner model is an autoregressive (dynamic) model and the least squares method used by its author because of the correlation of the explanatory variable with the random component is not the correct estimation method. Over time, the instrumental variable method (Angrist and Krueger, 2001) began to be used to estimate the time series models of individual companies and the method based on the first differences (Anderson and Hsiao, 1981) and the generalized method of moments (Arellano and Bond, 1991) to estimate panel models.

Despite the passage of years, Lintner's partial adjustment model is a very effective tool for analyzing companies' dividend policies.

The aim of the article is to show the usefulness of the Lintner model for analyzing changes in the company's dividend policy as measured by a dividend target payout ratio during the pandemic turmoil. For the illustration, Hydrotor SA was chosen. The choice of this company is not accidental for at least two reasons. Firstly, it is a joint stock company, which was founded in 1991 as a result of the so-called small privatization of a state agriculture machine centre, entered the Warsaw Stock Exchange and developed into a thriving company with a capitalization of 81 million PLN. Secondly, it is the company that pays dividends continuously the longest on the WSE (since IPO). It should be emphasized that there is very small number of companies paying dividends continuously for a long time on the WSE. Currently, only 10 quoted companies pay dividends continuously since IPO for more than 9 years.

For analyzing the impact of the coronavirus pandemic on the company's long-term dividend policy as measured by the dividend target payout ratio, Lintner model was used twice: firstly, to estimate the dividend target payout ratio on the basis of data from the period preceding the pandemic (2000-2019) and secondly, taking into account the period of the pandemic (20002020). Comparison of the target ratios for both periods allows an assessment of the impact of the pandemic on the company's dividend policy.

\section{Dividend target payout ratio in capital markets research worldwide and in Poland}

In his seminal work, Lintner (1956, p. 109) presented the results of estimation using the least squares method of a model based on data from 1918 to 1941 (excluding 1936 and 1937 because of the undistributed profits tax) and received two estimates:

$D_{t}=352,3+0,70 D_{t-1}+0,15 P w_{t}$ with profits adjusted for inventory gains

$D_{t}=160,0+0,788 D_{t-1}+0,145 P n_{t}$ when profits were unadjusted

In the first case, the dividend target payout ratio was $50.00 \%$, while in the second case it was $68.40 \%$. 
Fama and Babiak (1968) made a number of modifications to the Lintner model. They consisted of:

- replacing net profit as a variable describing income by cash-flow, which is the sum of net profit and depreciation and showing the free funds at the disposal of the company,

- extension of the model with another variable - depreciation,

- extension of the model with an additional variable in the form of a time lagged net profit (full adjustment model) (Fama and Babiak, 1968, p. 1142),

- deleting the constant.

Using data from 392 industrial companies over 19 years (1946-1964), they estimated the parameters of the proposed models and concluded that cash flow could be as good as net profit variable describing income, while removing constant and adding lagged net profit does not improve the quality of the model. The authors estimated, using the least squares method, cross-sectional models for each year and then averaged the parameters obtained. The tests used led them to conclude that autoregression does not have a major impact on the results obtained. Fama and Babiak's estimates show that the dividend target payout ratios ranged from $30.02 \%$ to $52.05 \%$. Dividends are slowly adjusting towards target payouts; adjusted speed does not exceed 0.5.

Cash-flow instead of net profit as a measure of income also introduced Renneboog and Szilagyi (2020) into Lintner's model in a study of 150 Dutch companies listed on Euronext Amsterdam and NMAX between 1996 and 2004. Based on this model, the dividend target payout ratio was $38.5 \%$.

Fernau and Hirsch (2019), after analyzing 979 models, found that $11.3 \%$ of them used cash-flow as an explanatory variable instead of net profit.

Fama and French (2002) made three further modifications. First, they proposed an analysis of dividend payments and debt, constructing a two-equations model. Secondly, they introduced additional control variables such as profitability, investment opportunities, profit volatility, tax shield into the Lintner model. Thirdly, they introduced non-linearity into the model. These modified models were estimated using data from 1965 to 1999 for 3,264 companies, of which 1,618 paid dividends. In view of the autoregressive nature of the models, they used the Famy-MacBeth method (1973) to estimate parameters each year on the basis of cross-sectional data and then to test the significance of the average parameters values over the whole period analyzed. Fama and French (2002, pp. 11-12) proposed that during the inference process the critical value of the t-statistic should be increased by 2.5 times due to autocorrelation over time. The models they propose give low average speed of adjustment (approx. 0.27). The dividend target payout ratio was between $32 \%$ and $33 \%$, depending on the model. This means that the target payout ratio is lower than the one observed in the sample (45\%).

Skinner (2008) estimated Lintner's cross-sectional-time series models for two sub-years, 1980 1994 and 1995-2004 for 345 U.S. companies that made at least 16 dividend payments between 1980 and 2005. The dividend target payout ratio for the first sub-period was $61.1 \%$ and for the second it was $55.2 \%$. This led the author to conclude that American companies are spending less and less profit on dividends and explains the increasing scale of their share repurchases.

Andres et al. (2015) applied the Lintner model to the 200 largest non-financial companies listed on the Frankfurt Stock Exchange over a period of 21 years (1988-2008). The sample 
they constructed included an average of $67.2 \%$ of the total German market capitalization. In the end, the panel consisted of 3960 observations. Depending on the estimation method, the dividend target payout ratio ranged from $23 \%$ in models estimated using within-group estimators, through $42 \%$ in models estimated by the least squares method to $48 \%$ in models estimated by generalized moment method.

Interesting studies of the impact of state treasuries from emerging markets of the EMEA Group (Europe, the Middle East, and Africa) on dividend decisions using the Lintner model were conducted by Nowak et al. (2017). The initial sample covered 2481 companies listed on the stock exchanges of 10 countries originating in the EMEA region (including Polish) over a period of twenty-two years: 1994-2015. After numerous exclusions resulting from the assumptions made, 371 companies were ultimately sampled, with 86 owned by the state. The authors used panel modelling methods to estimate parameters. The authors' estimated dividend target payout ratios ranged from 30\% in 1996 to $70 \%$ in 2014 .

Fernau and Hirsch (2019) analyzed 407 articles published in 8 databases of scientific journals since $1957^{1}$ on Lintner model estimates. ${ }^{2}$ They selected 99 articles, where estimates of 979 models were published. The fact that they did not include Lintner's article (1956) in which he formulated his model can be seen as an interesting matter. This was due to the fact that Lintner did not provide the value of standard errors of estimates and this statistic was one of the selection criteria. Using the collected data, they performed a regressive meta-analysis of the factors determining the values of the speed of adjustment (smoothing). When all control variables are included and GMMs are used as an estimation technique (and the net profit is accepted as a variable describing income), the calculations carried out by the authors determine the average speed of adjustment 0.464 (and the smoothing factor $1-0.464=0.536$ ) for non-financial firms (Fernau and Hirsch, 2019, p. 265). And while the work is not directly about the dividend payout ratio, it shows how popular the Lintner model is. They also showed that the results of such estimates were primarily published, indicating very high and statistically significant parameters values or very low and statistically insignificant parameters values. They also found that the results of Lintner model estimates published over many years depended on the ownership structure of the companies surveyed, but did not find a significant relationship between the results of the estimates and the size of the companies and the capital structure, as well as the countries in which the research was conducted. The results were influenced by the econometric estimation techniques used and in particular by the use of the GMM method for panel data.

According to Wójcikowska and Wójcikowski (2008, p. 321), Paliwoda (1997, p. 118-123) took the first attempt of the Lintner model estimation on the Polish capital market.

Wójcikowska and Wójcikowski (2008) analyzed all companies listed on the Warsaw Stock Exchange between 2001 and 2005, excluding banks. To estimate Lintner's models, they used data on companies that paid dividends in at least two consecutive years during that period. This resulted in about 150 observations. Income was measured using EBIT, cash-flow and net profit. The least squares method (cross-sectional-time series models) was used for estimation. The models were estimated separately for three ownership groups, with significant both parameters achieved for

\footnotetext{
${ }^{1}$ Among the articles examined, there was no one that treated Lintner models only for Polish companies.

${ }^{2}$ Selection based on the keywords "dividends", "payouts", "Lintner model", "dividend smoothing", "target payout", and "speed of adjustment".
} 
models of companies with highly fragmented shareholding (target payout ratio: 84.0\%) and with dominant private and corporate shareholding (target payout ratio: 68.4\%). In model with a dominant share of state-owned companies, the parameter on the lagged dividend was insignificant.

Kowerski (2013), using data on dividend payments on WSE between 1992 and 2012, estimated the Lintner model, which dependent variable was the dividend per company at constant prices paid for year $t$, while the explanatory variables were the dividend per company lagged by one year and the net profit per company at constant prices earned in year $t$. The estimated dividend target payout ratio was $80.4 \%$.

Gostkowska-Drzewicka and Majerowska (2016), analyzing the dividend policy of 17 construction companies listed on the Warsaw Stock Exchange between 2000 and 2014, built a Lintner model for each company using annual data. However, in the 7 estimated models, the parameters on lagged dividend had negative values, which is not in line with the Lintner model, while in the next 8 one or both parameters were insignificant. As a result, the target payout ratios can be calculated only for Elbudowa (31.6\%) and Budimex, although in the latter case it was $108.8 \%$ - this is possible but in the short term.

Kowerski and Wypych (2016) using Lintner models determined the impact of the ownership structure on the dividend target payout ratios of companies listed on the WSE (main market and NewConnect). Using an unbalanced panel of 71 companies (307 observations), which in 2012-2016 systematically paid dividends, they found that the dividend target payout ratio for the entire panel was $52.8 \%$. The highest dividend target payout ratio was for companies with a strategic investor (76.8\%). Companies with fragmented shareholding have a similar dividend target payout ratio (52.5\%) to all public sector companies $(51.3 \%)$. Lowest dividend target payout ratio (36.1\%) had companies with a financial investor. The dividend target payout ratio of companies in which the majority stake was held by a group of individuals was $47.1 \%$ (Kowerski and Wypych, 2016, p. 188).

\section{Subject and methodology of the study}

\subsection{Development of Hydrotor SA}

The origins of Hydrotor SA date back to 1945, when the State Company of Tractors and Agricultural Machinery was founded in Tuchola. Until 1966, the factory specialized in carrying out major repairs of tractor engines and the production of spare parts for agricultural machinery. On 1 January 1966, the company was transformed into the State Agriculture Machinery Centre (POM) and changed the business profile to regenerate spare parts and components for tractors and agricultural machinery by industrialized methods. In the 1970s, the production of hydraulic components began. In December 1991, during the privatization process, Hydrotor SA was founded on the basis of an existing state-owned company.

On 17 March 1998, the company was listed first on the Warsaw Stock Exchange. Since the entry into the stock exchange there has been a rapid development of the company. Net sales revenues increased from 22.3 million PLN at the end of 1998 to 72.4 million PLN in 2018 and 66.5 million PLN at the end of 2019 (average annual growth rate from 1998 to 2019 at current prices of 5.3\%). Total assets increased from 40.2 million PLN at the end of 1998 to 110.3 million PLN at the end of 2019 (by 4.9\% on average). During this time, equity in- 
creased from 27.6 million PLN to 81.1 million PLN (by 5.3\% on average per year). During the entire period of listening on the WSE, the company recorded net profits, although their values were subject to quite large fluctuations. In total, over 22 years at current prices, the company earned a net 108.8 million PLN, while at 2020 prices 125.9 million PLN. ${ }^{3}$

The company's share prices were subject to changes similar to those of the market as a whole. Sharpe's model estimated on annual data (Sharpe, 1963) took the form of:

$$
\begin{aligned}
& R=5,00 \\
& p: \quad+0,6556 /
\end{aligned} \quad \begin{aligned}
& 1,08 R_{W I G} \\
&
\end{aligned} \quad R^{2}=0,0168 / 2658
$$

This means that investing in Hydrotor stocks during the analysis period was slightly riskier than market risk. Based on Sharpe's model, market risk accounted for $26.58 \%$ of the total risk and specific risk was $73.42 \%$.

\subsection{Dividend payments by Hydrotor SA}

Hydrotor is a WSE-listed company that pays dividends longest, continuously. Since entering the stock exchange in 1998 to 2020 it has made 22 payouts.

The directions of changes in the value of dividends and net profits were quite similar. The correlation coefficient between net profits in the years 1998-2019 and dividends paid for these period (in current prices) was 0.855 ( $\mathrm{p}<0.0001$ ). In 1999, the company paid dividends for the previous year worth 1.25 million PLN. In the following years, payments increased to a maximum of 5.04 million PLN for 2007. Then, by the end of 2010, there was a decrease in dividend payments. Dividend payments for the period 2012-2017 were the same (4.80 million). The maximum payout for 2007 was repeated with the payment for 2018 .

In 2020, for 2019, the company decided to pay a dividend of only 2.4 million PLN (more than half less than a year earlier). One of the reasons for such a decision may have been a coronavirus pandemic, although the company makes no mention of this in its Decision no. 18/ $\mathrm{VI} / 2020$ of 27 June 2020 on profit-sharing. But in the Report on the activities of Hydrotor SA and Hydrotor Capital Group in the first half of 2020, the Board writes that

$[\ldots]$ in the first half of the year, the decrease in sales revenues by $14 \%$ due to a significant reduction in foreign sales is mainly caused by the coronavirus pandemic (Hydrotor SA, 2020, p. 9).

There is a risk of problems with the supply of basic raw materials and materials for production, as well as unpredictable absenteeism due to mandatory quarantine and illness. There is a noticeable reduction in orders from foreign companies. The consequence of the economic turmoil is a significant weakening of the zloty, which may affect the valuation of concluded contracts protected margin on sales of products, services and goods, which in effect will result in an additional decrease in the financial result generated by the Company (Hydrotor SA, 2020, p. 41).

The reduction in dividends paid in 2020 may also have been due to the fact that 2019 was the fourth consecutive year of decline in net profit.

The Company paid a total of 65.2 million PLN in dividends (in current prices) for the years 1998-2019, which is equal to 75.7 million PLN in 2020 prices.

\footnotetext{
${ }^{3}$ Annual Consumer Price Indexes (CPI) were used for the conversion into 2020 prices (https://stat.gov.pl/ wskazniki-makroekonomiczne/) [accessed: 2021-09-04].
} 
The dividend payout ratio showed a growing trend and ranged from $29.1 \%$ for 1998 to $88.5 \%$ for 2013 and $84.4 \%$ for 2018 . The payout ratio for 2019 was more than half less than a year earlier $(41.7 \%)$. The average dividend payout over the whole period considered at constant prices was $58.3 \%$.

The dividends paid by the company significantly improved the income received by shareholders. If an investor bought the shares at the day of the company's entry into the WSE and sold them at the end of 2019, he would gain 34.57 PLN per share, which would give a total rate of return of $49 \%$. As a result of the increase in prices, however, the investor would earn only $7.40 \mathrm{PLN}$, which is $15 \%$ of the total gains thus $85 \%$ of the investor's gains are the incomes derived from dividends paid.

\subsection{Data}

The study covered the period from the company's entry into the WSE (17 March 1998) to the payment of the last dividend (8 September 2020). The microeconomic data of the company was taken from the bankier.pl website and WSE yearbooks, the data on dividend policy comes from the resolutions of the Hydrotor AGMs, the data on share prices were taken from bossa.pl website and the value of stock indices from gpw.pl website.

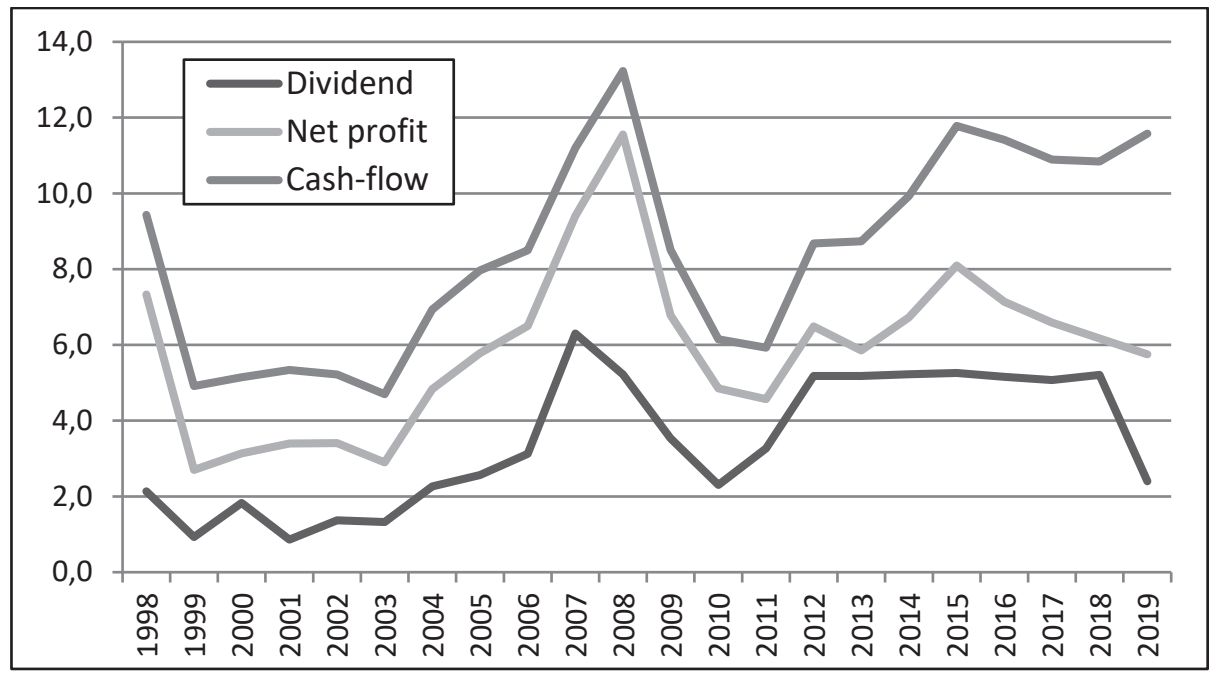

Figure 1. Changes in net profits and cash-flow between 1998 and 2019 and dividend payments for 1998-2019 of Hydrotor SA at 2020 prices (million PLN)

S o u r c e: Authors' own elaboration. 
Due to the delay in the time of the endogenous explanatory variable by one year and the instrumental variables (by two years), the calculation was made for dividend payments for the period 2000-2019. However, in order to capture the impact of the pandemic on the company's dividend target payout ratio, the payout models for the period 2000-2018 were additionally estimated.

\subsection{Lintner's dynamic dividend policy model and estimation methods}

John Lintner's 1956 interviews with board members of New York Stock Exchange-listed companies made the following conclusions:

- companies use long-term dividend payout targets;

- company management is more focused on dividend changes than on its value;

- payments follow long-term changes in the level of net profit earned; short-term changes in profits are unlikely to affect the payment of dividends;

- boards are reluctant to decide to change the dividend level.

This, in turn, led Lintner to build a partial adjustment model, in which the dividend paid for year $t$ depends on the income earned in that year and on the dividend paid for the previous year:

$D_{t}=\alpha_{0}+\alpha_{1} D_{t-1}+\alpha_{2} P_{t}+\varepsilon_{t}$

$D_{t}-$ dividend for year $t$

$P_{t}-$ income measured by net profit in year $t$

$\alpha_{0}, \alpha_{1}, \alpha_{2}-$ structural parameters

$\varepsilon_{t}-$ random component

With the estimated structural parameters of the above model, two basic indicators characterizing the company's long-term dividend policy can be calculated:

- dividend target payout ratio: $\tau=\frac{a_{2}}{1-a_{1}}$

- speed of adjustment: $1-a_{1}$

It should also be stressed that the estimated values of the $\alpha_{1}, \alpha_{2}$ should be proper fractions.

The main problem with Lintner model estimation is that it is an autoregressive (dynamic) model in which one of the explanatory variables is a lagged dependent variable (dividend lagged by one year $D_{t-1}$ ). This indicates a non-zero correlation between the random component and this variable. Therefore, the least squares method gives an inconsistent estimator and should not be used. The method giving a compatible estimator is the two stage least squares method, which in the case of one-equation time series models is called the instrumental variable method (Angrist and Krueger, 2001). ${ }^{4}$ It consists in using the least squares method twice. In the first stage, it is used to estimate the parameters of the $D_{t-1}$ model on selected instruments. In the second stage it is used to estimate the parameters of the model of variable $D_{t}$ on the theoretical values $\widehat{D_{t-1}}$ calculated at the first stage and the variable $P_{t}$ (Maddala, 2020, pp. 508-511). In this method very difficult problem, which has not yet been conclusively solved, is the selection of instrumental variables. A "good" instrument is a variable that correlated with the variable for which we need the instrument, but is not correlated with the random component of the estimated equation. In the context of time series, it is usually used as instruments of observation from the previous period.

\footnotetext{
${ }^{4}$ The theory of instrumental variables was first introduced by Philip G. Wright in his 1928 publication.
} 
Since autocorrelation is common in time series, this means that the instrument will be correlated with the explanatory variable. Assuming that the random component is not autocorrelated, the instrument will not be correlated with it (Koop, 2014, p. 178). Therefore, $D_{t-2}$ was introduced as one of the instruments for $D_{t-1}$. Since the variable $D_{t}$ depends on a predetermined variable $P_{t}$ (i.e. it is not correlated with a random component), it can be assumed that the variable $D_{t-1}$ will also be correlated with variables $P_{t}$ and $P_{t-1}$, which become successive instrumental variables (Maddala, 2020, p. 652). Then again, on the assumption that the instruments should reflect both the situation within the company and in its surroundings as instrumental variables, three macroeconomic variables were adopted: annual GDP growth rate $\left(P K B_{t}\right)$, the annual rate of inflation $\left(\operatorname{Inf} f_{t}\right)$ and the annual rate of return of WSE main index $\left(W I G_{t}\right)$.

To verify that the estimator is consistent, the Hausman test was applied, whether the instruments are valid-Sargan over-identification test (Cottrell and Lucchetti, 2021, pp. 208, 224) was applied, whether all instruments are strong - Weak instrument test was applied (Stock and Yogo, 2005), whether there is autocorrelation of random components in autoregressive model-LM test was applied (Greene, 2003, p. 271), whether random components are homoscedastic-Pesaran-Taylor test was applied (Pesaran and Taylor, 1999).

The goodness of fit between the model and the empirical data was measured with a coefficient of determination $\left(R^{2}\right)$.

The Lintner model can also be output from an infinite-distributed-lag model, assuming that the value of the dividend paid for year $t$ depends on net profits in year $t$ and in previous years, and the parameters form a decreasing geometric sequence over time (Kowerski, 2011, p. 75):

$D_{t}=\frac{a_{0}}{1-a_{1}}+\alpha_{2} P_{t}+\alpha_{2} \alpha_{1} P_{t-1}+\alpha_{2} \alpha_{1}{ }^{2} P_{t-2}+\alpha_{2} \alpha_{1}^{3} P_{t-3}+\cdots \varepsilon_{t}$

\subsection{Procedure for investigating the impact of the coronavirus pandemic on the dividend target payout ratio of Hydrotor SA}

The procedure consists of four stages:

1. Estimation the Lintner model of payments for the period 2000-2018 and calculation of the dividend target payout ratio based on it. This model describes the company's prepandemic payout policy.

2. Formulation on the base of estimated for the period 2000-2018 model (which does not embrace coronavirus pandemic) the dividend payment forecast in 2020. The size of the difference between the projected and the actual dividend will show the scale of influence of events in 2020 on the company's decisions.

3. Estimation the Lintner model of payments for the period 2000-2019 and calculation of the dividend target payout ratio based on it. This model describes the company's payout policy including the pandemic.

4. Comparison of the dividend target payout ratios calculated using both models and drawing conclusions. 


\section{Lintner model estimation results for Hydrotor}

The GRETL software (Cottrell and Lucchetti, 2021), (Kufel, 2018) was used to estimate Lintner models for dividend payments for the years 2000-2018 and 2000-2019.

Table 1. Lintner instrumental variable method estimation results for Hydrotor SA

\begin{tabular}{|c|c|c|c|c|}
\hline \multicolumn{3}{|c|}{ Parameters and coefficients } & $\begin{array}{l}\text { Model } 1 \\
\text { Payouts for the years } \\
2000-2018\end{array}$ & $\begin{array}{l}\text { Model } 2 \\
\text { Payouts for the years } \\
\text { 2000-2019 }\end{array}$ \\
\hline \multirow{2}{*}{ Parameter $\alpha_{1}$} & \multicolumn{2}{|l|}{ value } & 0.3740 & 0.3173 \\
\hline & \multicolumn{2}{|l|}{$p$ level } & 0.0057 & 0.0593 \\
\hline \multirow{2}{*}{ Parameter $\alpha_{2}$} & \multicolumn{2}{|l|}{ value } & 0.4286 & 0.4467 \\
\hline & \multicolumn{2}{|l|}{$p$ level } & 0.0236 & 0.0017 \\
\hline \multicolumn{3}{|c|}{ Dividend target payout ratio (\%) } & 68.48 & 65.44 \\
\hline \multicolumn{3}{|c|}{ Speed of adjustment } & 0.6260 & 0.6827 \\
\hline \multicolumn{3}{|l|}{$\mathrm{R}^{2}$} & 0.7392 & 0.6901 \\
\hline \multirow{2}{*}{\multicolumn{2}{|c|}{ F statistic }} & value & 20.9756 & 20.5789 \\
\hline & & $p$ level & $<0.0001$ & $<0.0001$ \\
\hline \multirow{2}{*}{\multicolumn{2}{|c|}{$\begin{array}{l}\text { Hausman test } \\
\text { Null hypothesis: OLS estimates are consistent } \\
\chi^{2}(1) \text { statistic }\end{array}$}} & value & 0.0213 & 0.0582 \\
\hline & & $p$ level & 0.8840 & 0.8094 \\
\hline \multirow{2}{*}{\multicolumn{2}{|c|}{$\begin{array}{l}\text { Sargan over-identification test } \\
\text { Null hypothesis: all instruments are valid } \\
\text { LM statistic }\end{array}$}} & value & 8.7681 & 8.4161 \\
\hline & & $p$ level & 0.0672 & 0.0775 \\
\hline \multicolumn{3}{|c|}{$\begin{array}{l}\text { Weak instrument test } \\
\text { First-stage F statistic }\end{array}$} & 11.5973 & 14.315 \\
\hline \multirow{2}{*}{\multicolumn{2}{|c|}{$\begin{array}{l}\text { Pesaran-Taylor test for heteroskedasticity } \\
\text { Null hypothesis: heteroskedasticity not present } \\
\text { z asymptotic statistic }\end{array}$}} & value & 1.8841 & 1.4584 \\
\hline & & $p$ level & 0.0596 & 0.1447 \\
\hline \multirow{2}{*}{\multicolumn{2}{|c|}{$\begin{array}{l}\text { LM test for autocorrelation up to order } 1 \\
\text { Null hypothesis: no autocorrelation } \\
\text { LMF statistic }\end{array}$}} & value & 1.3652 & 1.2008 \\
\hline & & $p$ level & 0.2609 & 0.2894 \\
\hline
\end{tabular}

S o u r c e: Author's own calculations in GRETL.

The estimated models meet the basic formal validation criteria assigned to the instrumental variables method: 
- The estimator used is consistent which denotes Hausman's test (there is no reason to reject the null hypothesis of the estimator consistent).

- The instruments adopted are valid, as indicated the Sargan test (there is no reason to reject the null hypothesis of the validity of the instruments).

- All instruments are strong as indicated the Weak instrument test, F statistic value greater than 10.

- According to the Pesaran-Taylor test, in the model, random components are homoscedastic (there is no reason for rejecting the null hypothesis that heteroskedasticity is not present).

- According to the LM test, there is no autocorrelation of the first order of random components in the model (there is no reason to reject the null hypothesis that there is no autocorrelation of random components).

- Parameters $\alpha_{1}$ and $\alpha_{2}$ are significant at 0.05 in the 2000-2018 model, while in the 20002019 model, the $\alpha_{2}$ is significant at 0.06 .

- Together, the two explanatory variables describe the volatility of dividend payments in a significant way, as indicated by the significance of the multiple correlation coefficient ( $F$-test).

The estimated models also meet the substantive criteria: the values of both estimated parameters are proper fractions, which is in line with the Lintner model.

In 2019, the company made a net profit of 5753.1 thousand PLN. By inserting this value into the estimated payout model for 2000-2018 (model 1) and the dividend paid in 2019 (5207.7 thousand PLN), we receive a projected dividend which the company should pay in 2020, assuming that in 2020 the company would continue its current payout strategy - there will be no coronavirus pandemic. Its amount is 4345.4 thousand PLN. In fact, in 2020, the company paid a dividend of 2398.3 PLN, i.e. $44.8 \%$ less, which may have been due to pandemic shock.

Based on the payout model for 2000-2018, the calculated dividend target payout ratio was $68.48 \%$. In 2020, when the company significantly reduced the level of dividend payment, the dividend target payout ratio, calculated on the basis of the payout model for the period 20002019 , decreased by 3.04 percentage points (to $65.04 \%$ ). However, the speed of the adjustment increased (smoothing out of payouts decreased) from 0.63 to 0.68 . This means an increase in the dependence of dividend payments on current net profits. The model's determination coefficient for payouts for the period 2000-2019 compared to the model not taking into account last year has also decreased (by 0.049 to 0.69 ). Thus, the situation that occurred in 2020 resulted in a revision of the company's long-term dividend strategy and paying more attention to the current situation (current net profits distributions). 


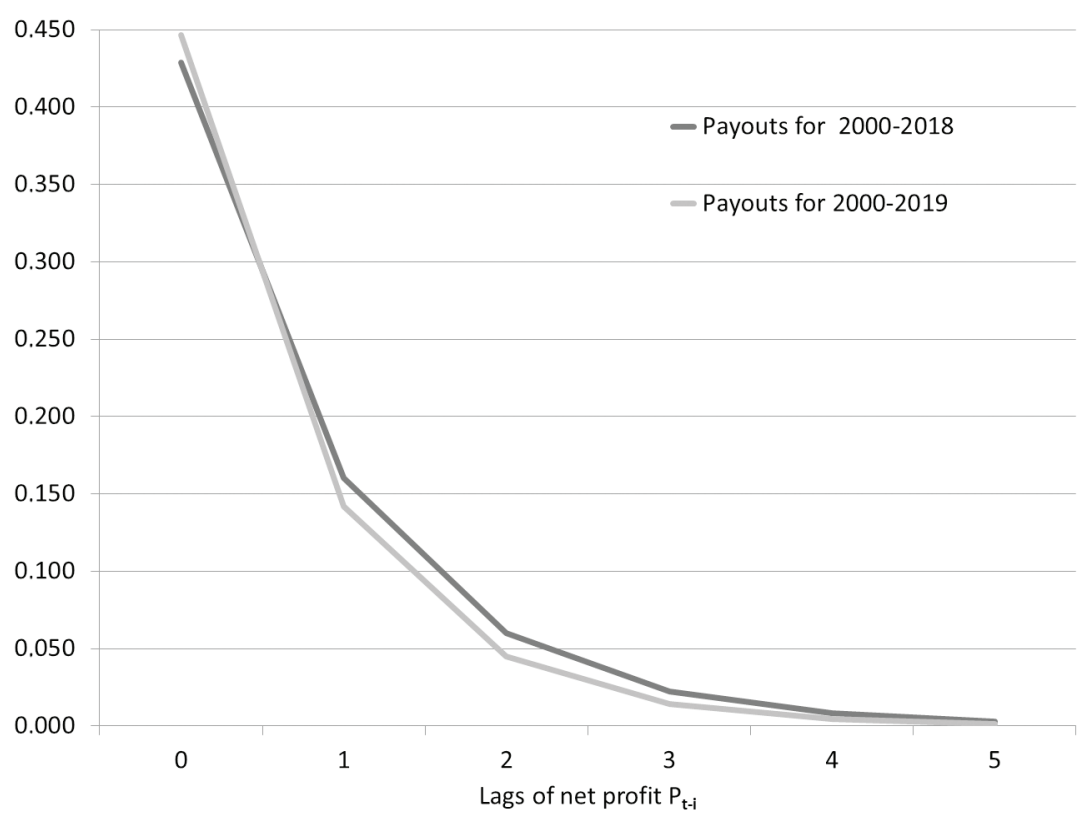

Figure 2. Distribution of parameters at profit and its delays estimated on the basis of the model (6)

S o u r c e: Authors' own elaboration.

Although the differences between the parameter distributions in the two models are small, it can be seen (Figure 2) that in the payout model for the years 2000-2019 only the profit in year $t$ has a greater impact on the dividend value than in the 2000-2018 model.

Also there were estimated payout models in which net profit was replaced by cash flow, which is the sum of net profit and depreciation. ${ }^{5}$ While in the 2000-2018 payout model both parameters were proper fractions, although the $\alpha_{1}$ was statistically insignificant, in the 2000 2019 payout model parameter $\alpha_{1}$ was negative, which does not allow to calculate the dividend target payout ratio or the speed of the adjustment. That is, in fact, not a Lintner model.

\section{Summary}

In our opinion, Lintner's model is a good tool for analyzing the impact of the coronavirus pandemic (as well as other shocks) on the company's long-term dividend policy as measured by the dividend target payout ratio. This model should be used twice: firstly, to estimate the dividend target payout ratio on the basis of data from the period preceding the pandemic (shock) and secondly, taking into account the period of the pandemic. Comparison of the target ratios for both periods allows an assessment of the impact of the pandemic on the company's dividend policy.

\footnotetext{
${ }^{5}$ The results can be made available by authors.
} 
The correctness of such proceeding was confirmed by the example of the company that has the longest dividend payout history on the WSE (22 years)-Hydrotor SA. The calculations showed that the Hydrotor situation in 2020 resulted in a revision of the company's long-term dividend strategy, which resulted in a lowering of the dividend target payout ratio and a greater attention to the current situation (current net profits) - an increase in the speed of adjustment. However, 2021 will give an answer to what degree the changes observed are permanent.

\section{References}

Anderson, T. W., Hsiao, C. (1981). Estimation of dynamic models with error components. Journal of American Statistical Association, 76(375), 598-606. DOI: 10.2307/2287517.

Andres, Ch., Doumet, M., Fernau, E., Theissen, E. (2015). The Lintner model revisited: Dividends versus total payouts. Journal of Banking \& Finance, 55, 56-69. DOI: 10.1016/j.jbankfin.2015.01.005.

Angrist, J. D., Krueger, A. B. (2001). Instrumental variables and the search for identification: From supply and demand to natural experiments. Journal of Economic Perspectives, 15(4), 69-85.

Arellano, M., Bond, S. (1991). Some tests of specification for panel data: Monte Carlo evidence and an application to employment equations. Review of Economic Studies, 58(2), 277-297. DOI: $10.2307 / 2297968$.

Cottrell, A., Lucchetti, R. (2021). Gretl user's guide [online, accessed: 2021-03-03]. Retrieved from: http:// ricardo.ecn.wfu.edu/pub/gretl/gretl-guide.pdf.

Fama, E. F., French, K. R. (2002). Testing trade-off and pecking order predictions about dividends and debt. The Review of Financial Studies, 15(1), 1-33. DOI: 10.1093/rfs/15.1.1.

Fama, E., Babiak, H. (1968). Dividend policy: An empirical analysis. Journal of the American Statistical Association, 63(324), 1132-1161.

Fama, E. F., MacBeth, J. D. (1973). Risk, return and equilibrium: Empirical tests. Journal of Political Economy, 81(3), 607-636.

Fernau, E., Hirsch, S. (2019). What drives dividend smoothing? A meta regression analysis of the Lintner model. International Review of Financial Analysis, 61, 255-273.

Gostkowska-Drzewicka, M., Majerowska, E. (2016). The relevance of dividend smoothing in the construction companies listed on the Warsaw Stock Exchange. Nauki o Finansach / Financial Sciences, 2(27), 9-22. DOI: $10.15611 /$ nof.2016.2.01.

Greene, W. H. (2003). Econometric Analysis. th $^{\text {th }}$ ed. Upper Saddle River. NJ: Pearson Eduction, Inc. ISBN 0130661899.

Hydrotor SA. (2020). [online, accessed: 2021-03-03]. Report on the activities of Hydrotor SA and Hydrotor Capital Group in the first half of 2020. Retrieved from: http://www.hydrotor.pl/relacje-inwestorskie/\#1460668645137-c1c56e1b-306a.

Koop, G. (2014). Wprowadzenie do ekonometrii. Warszawa: Oficyna a Wolters Kluwer business. ISBN 9788326431913.

Kowerski, M. (2011). Ekonomiczne uwarunkowania decyzji o wypłatach dywidend przez spótki publiczne. Wydawnictwo Konsorcjum Akademickie: WSE w Krakowie, WSIZ w Rzeszowie, WSZiA w Zamościu. ISBN 9788362259281.

Kowerski, M. (2013). Model częściowych dopasowań dywidend Lintnera dla Giełdy Papierów Wartościowych w Warszawie. Annales Universitatis Mariae Curie-Skłodowska. Sectio H, Oeconomia, 47(3), 337346. DOI: 10.17951/h.2013.47.3.337.

Kowerski, M., Wypych, M. (2016). Ownership structure and dividend strategy of public companies. Evidence from Poland. Barometr Regionalny. Analizy i Prognozy, 14(4), 179-192.

Kufel, T. (2018). Ekonometria: Rozwiąywanie problemów z wykorzystaniem programu GRETL. Warszawa: Wydawnictwo Naukowe PWN. ISBN: 9788301165130.

Lintner, J. (1956). Distribution of incomes of corporation among dividends, retained earnings and taxes. American Economic Review, 46(2), 97-113.

Maddala, G. S. (2020). Ekonometria. Warszawa: Wydawnictwo Naukowe PWN. ISBN 9788301156947. 
Nowak, S., Mosionek-Schweda, M., Mrzygłód, U., Kwiatkowski, J. (2017). Greedy state? The effect of the government shareholder on the dividend payout ratio and smoothing levels. International Journal of Contemporary Management, 16(4), 119-143. DOI: 10.4467/24498939IJCM.17.041.8264.

Paliwoda, G. (1997). Przegląd matematycznych modeli ustalania poziomu wypłat dywidendy. Zeszyty Naukowe AE w Krakowie, 480, 75-83.

Pesaran, M. H., Taylor, L. (1999). Diagnostics for IV regressions. Oxford Bulletin of Economics and Statistics, 61(2), 255-281.

Renneboog, L., Szilagyi, P. G. (2020). How relevant is dividend policy under low shareholder protection. Journal of International Financial Markets Institutions and Money, 64, 1-18. DOI: 10.1016/j. intfin.2015.01.006.

Sharpe, W. F. (1963). A simplified model of portfolio analysis. Management Science, 9/2, 277-293.

Skinner, D. J. (2008). The evolving relation between earnings, dividends, and stock repurchases. Journal of Financial Economics, 87(3), 582-609.

Stock, J., Yogo, M. (2005). Testing for weak instruments in linear IV regression. In: D. W. K. Andrews (ed.). Identification and inference for econometric models (pp. 80-108). New York: Cambridge University Press. ISBN 9780521844413.

Wójcikowska, U., Wójcikowski, R. (2008). Polityka dywidendy a struktura akcjonariatu: studium przypadku z użyciem modelu Lintnera. Studia i Prace Wydziatu Nauk Ekonomicznych i Zarządzania Uniwersytetu Szczecińskiego, 10, 320-326.

Wright, P. G. (1928). Appendix B: Effects of a duty on price and output with special reference to butter and flaxseed. In: P. G. Wright (ed.). The tariff on animal and vegetable oils (pp. 286-319). New York: MacMillan.

\section{Wpływ pandemii koronawirusa na docelową stopę wypłaty dywidendy. Przykład Hydrotor SA}

\begin{abstract}
Abstrakt: Zaproponowany przez Lintnera (1956) model częściowych dopasowań pozwala zidentyfikować długoterminową politykę dywidendową spółki poprzez określenie docelowej stopy wypłaty dywidendy i szybkości dopasowania się do niej wypłat. I chociaż w ciągu ponad 60 lat model przeszedł różne modyfikacje i zmieniały się metody jego estymacji, to jest on nadal dobrym narzędziem analizy decyzji dywidendowych podejmowanych przez spółki. Celem artykułu jest pokazanie przydatności modelu Lintnera do analizy zmian polityki dywidendo-
\end{abstract}

wej spółki w okresie zawirowań związanych z pandemią koronawirusa. Do ilustracji wybrano spółkę Hydrotor SA, która najdłużej na GPW w Warszawie nieprzerwanie wypłaca dywidendę. Przeprowadzone obliczenia pokazały, że sytuacja, która nastąpiła w 2020 r., spowodowała zrewidowanie długoterminowej strategii dywidendowej spółki, której konsekwencją było obniżenie docelowej stopy wypłaty dywidendy i większe uzależnienie wypłat od bieżącej sytuacji (bieżących zysków netto) - wzrost szybkości dopasowania.

Słowa kluczowe: model Lintnera, docelowa stopa wypłaty dywidendy, pandemia koronawirusa, Hydrotor SA 